http://jmscr.igmpublication.org/home/ ISSN (e)-2347-176x ISSN (p) 2455-0450 crossref DOI: https://dx.doi.org/10.18535/jmscr/v8i4.36

\title{
Association of Diabetic Maculopathy with Common Systemic Comorbidities
}

\author{
Authors \\ Nethaji Sellaram $\mathbf{S} *$, Dalia $\mathbf{S}$ \\ Department of Ophthalmology, Govt. TD Medical College, Alappuzha, Kerala - 688005, India \\ *Corresponding Author \\ Nethaji Sellaram S
}

\begin{abstract}
Purpose: To identify association of diabetic maculopathy with factors like hypertension, coronary artery disease (CAD), fasting lipid profile, serum urea and creatinine, HbAlc.

Design: Cross sectional study.

Materials and Methods: 150 patients were enrolled, their diabetic retinopathy and maculoapthy status were assessed. Optical coherence tomography (OCT) scan of macula was done. Patients systemic factors were assessed using clinical and laboratory tests.

Results: Out of 150 patients 50\% had moderate NPDR, $22.7 \%$ with severe NPDR, $22.7 \%$ with PDR, $4.7 \%$ with mild NPDR changes. $84 \%$ of patients were having severe diabetic maculopathy. Duration of diabetes and hypertension, CAD showed no significant difference with the maculopathy severity. HDL cholesterol level showed signification association with diabetic maculoathy. HDL, LDL, urea, creatinine, HbAlc levels showed significant association with increase in central foveal thickness.

Conclusion: Poor glycemic control, hyperlipidemia and deranged renal function found to increase the diabetic macular edema.

Keywords: Diabetic Maculopathy; association; risk factors; OCT.
\end{abstract}

\section{Introduction}

India has $1 / 4^{\text {th }}$ of the world's total blind population, that is 12 million people have visual acuity less than $6 / 60$ in the better eye. Of this diabetes stands among sixth most frequent cause of blindness. WHO estimated that in India, the number of diabetes will be highest in the world. According to WHO 31.7 million people were affected by diabetes mellitus and this figure is estimated to rise to 79.4 million by 2030 , the largest number in any nations in the world. Microvascular complications like retinopathy, nephropathy, neuropathy are linked to the duration of diabetes mellitus, poor glycemic control and systolic hypertension. Dyslipidemiahas been implicated as an independent risk factor for vision loss and diabetic macular edema. ${ }^{1}$ Hypertension significantly exacerbates vision loss from macular edema. $^{2}$

\section{Aim of Study}

To identify association of diabetic maculopathy with factors like hypertension, coronary artery disease (CAD), fasting lipid profile, serum urea and creatinine, $\mathrm{HbA} 1 \mathrm{c}$.

\section{Inclusion Criteria}

1) Diabetic maculopathy patients (type I and type II)

2) Patients above 18 years of age 


\section{Exclusion Criteria}

Treated cases of diabetic retinopathy

\section{Materials and Methods}

Study was conducted in retina clinic in department of Ophthalmology outpatient department of government T.D. Medical College and Hospital, Alappuza. 150 patients who satisfied the inclusion criteria were enrolled. Detailed history was elicited and complete ophthalmic examination was done which included recording the best corrected visual acuity, anterior segment examination with slit lamp, fundus examination after dilating with $0.8 \%$ of tropicamide and $5 \%$ phenylephrine using 90 dioptre lens. Severity of retinopathy and maculopathy were graded according to the International Clinical Diabetic Retinopathy and Macular Edema Disease Severity Scale. OCT scanning of macula was done using Carl Zeiss Cirrus HD-OCT model 4000.Using macular cube $512 \times 128$ scan, central foveal thickness was measured and its association was with risk factors were studied. Age, duration of diabetes, hypertension, $\mathrm{CAD}$ and its association with maculopathy were studied. Fasting lipid profile, urea, creatinine, HbA1c levels were tested and their association with diabetic maculopathy severity and central foveal thickness (CFT) were assessed. Data was analysed using computer software, Statistical Package for Social Sciences (SPSS) version 16. Data are expressed in frequency and percentage. For all statistical evaluations, probability of value ( $p$ value), $<0.05$ was considered significant

\section{Results}

Out of 150 patients enrolled in our study 60 patients were males and 90 patients were females

Table 1: Diabetic retinopathy distribution

\begin{tabular}{|l|c|c|}
\hline Diabetic retinopathy & Frequency & Percentage \\
\hline Mild NPDR & 7 & 4.7 \\
\hline Moderate NPDR & 75 & 50.0 \\
\hline Severe NPDR & 34 & 22.7 \\
\hline PDR & 34 & 22.7 \\
\hline Total & 150 & 100.0 \\
\hline
\end{tabular}

In our study more number of patients, around 50\% of patients were having moderate non proliferative diabetic retinopathy (NPDR).

Table2: Diabetic maculopathy distribution

\begin{tabular}{|l|c|c|}
\hline Diabetic maculopathy & Frequency & Percentage \\
\hline Mild & 11 & 7.3 \\
\hline Moderate & 13 & 8.7 \\
\hline Severe & 126 & 84.0 \\
\hline Total & 150 & 100.0 \\
\hline
\end{tabular}

In our study $126(84 \%)$ patients had severe diabetic macular edema, $8.7 \%$ were having moderate and and $7.3 \%$ with mild diabetic macular edema

\section{Age and Maculopathy}

Maximum number patient were in the age group 31 to 70 years $(\sim 90 \%)$. No statistical difference was observed between age and diabetic maculopathy patients, though proportion severe macular edema was seen more in age of 51 to 70 years compared to the younger age group

Table 3: Age distribution

\begin{tabular}{|l|c|c|}
\hline Age & Frequency $(\mathbf{n})$ & Percentage $\mathbf{( \% )}$ \\
\hline $18-30$ years & 3 & 2.0 \\
\hline $31-50$ years & 55 & 36.7 \\
\hline $51-70$ years & 79 & 52.7 \\
\hline$>70$ years & 13 & 8.7 \\
\hline Total & 150 & 100.0 \\
\hline
\end{tabular}

Table 4: Age and diabetic maculopathy

\begin{tabular}{|l|c|c|c|c|c|}
\hline AGE & \multicolumn{3}{|c|}{ Diabetic maculopathy } & \multirow{2}{*}{$\begin{array}{c}\text { Chi } \\
\text { square }\end{array}$} & $\begin{array}{c}\text { P } \\
\text { value }\end{array}$ \\
\hline & mild & moderate & severe & \multirow{2}{*}{9.308} & 0.157 \\
\cline { 1 - 4 } 18-30 years & 0 & 0 & 3 & & \\
\hline 31-50 years & 8 & 6 & 41 & & \\
\hline 51-70 years & 3 & 7 & 69 & & \\
\hline$>70$ years & 0 & 0 & 13 & & \\
\hline
\end{tabular}

\section{Duration of Diabetes, Hypertension, CAD and Diabetic Maculopathy}

There is no statistically significant difference observed between duration of diabetes, hypertension, CAD and diabetic maculopathy

Table 5: Duration of Diabetes and Maculopathy

\begin{tabular}{|l|c|c|c|c|c|}
\hline \multirow{2}{*}{$\begin{array}{l}\text { Duration of } \\
\text { diabetes }\end{array}$} & \multicolumn{3}{|c|}{ Diabetic maculopathy } & \multirow{2}{*}{$\begin{array}{c}\text { Chi } \\
\text { square }\end{array}$} & $\begin{array}{c}\text { P } \\
\text { value }\end{array}$ \\
\cline { 2 - 4 } & Mild & Moderate & Severe & 7.136 & 0.308 \\
\hline 1-5 years & 1 & 5 & 21 & & \\
\hline 6-10years & 2 & 4 & 45 & & \\
\hline 11-15years & 4 & 2 & 25 & & \\
\hline$>15$ years & 4 & 2 & 35 & & \\
\hline
\end{tabular}


Table 6: Duration of Hypertension and Maculopathy

\begin{tabular}{|l|c|c|c|c|c|}
\hline \multirow{2}{*}{$\begin{array}{l}\text { Duration of } \\
\text { hypertension }\end{array}$} & \multicolumn{3}{|c|}{ Diabetic maculopathy } & \multirow{2}{*}{$\begin{array}{c}\text { Chi } \\
\text { square } \\
\text { value }\end{array}$} & \\
\hline & Mild & Moderate & Severe & 6.475 & \multirow{2}{*}{0.372} \\
\hline 1-5 years & 1 & 3 & 17 & & \\
\hline 6-10 years & 0 & 1 & 11 & & \\
\hline 11-15 years & 2 & 0 & 12 & & \\
\hline$>15$ years & 2 & 0 & 11 & & \\
\hline
\end{tabular}

Table 7: Duration of Coronary artery disease (CAD) and maculopathy

\begin{tabular}{|l|l|l|l|l|}
\hline \multirow{2}{*}{$\begin{array}{l}\text { Duration of } \\
\text { CAD }\end{array}$} & \multicolumn{2}{|l|}{$\begin{array}{l}\text { Diabetic } \\
\text { maculopathy }\end{array}$} & \multirow{2}{*}{$\begin{array}{l}\text { Chi } \\
\text { square }\end{array}$} & \multirow{2}{*}{ P value } \\
\cline { 2 - 3 } & Moderate & Severe & 0.321 & 0.571 \\
\hline 1-5years & 1 & 6 & & \\
\hline 6-10years & 0 & 2 & & \\
\hline
\end{tabular}

In the fasting lipid profile only HDL cholesterol level had significant association with macular edema (p-0.02), in that mild diabetic macular edema $3(60 \%)$ patients had HDL<40, 2(40\%) had HDL level of 40 to $60 \mathrm{mg} / \mathrm{dl}$. Moderate diabetic macular edema $9(75 \%)$ had $\mathrm{HDL}<40 \mathrm{mg} / \mathrm{dl}$, $3(25 \%)$ had HDL 40 to $60 \mathrm{mg} / \mathrm{dl}$. Severe diabetic macular edema patients 40(30.8\%) had HDL $<40 \mathrm{mg} / \mathrm{dl}, 75(56.39 \%)$ had HDL 40 to $60 \mathrm{mg} / \mathrm{dl}$, $18(13.3 \%) \mathrm{HDL}>60 \mathrm{mg} / \mathrm{dl}$. Other factors urea, creatinine, HbA1c didn't show significant association with severity of macular edema.

Table 8: Diabetic maculopathy and risk factors

\begin{tabular}{|c|c|c|c|c|c|c|c|c|c|}
\hline \multirow{3}{*}{\multicolumn{2}{|c|}{ Risk factors(mg/dl, except HbA1C) }} & \multirow{3}{*}{$\begin{array}{c}\text { Total } \\
(\mathrm{n}=150)\end{array}$} & \multicolumn{6}{|c|}{ MACULOPATHY } & \multirow[t]{3}{*}{ p-value } \\
\hline & & & \multicolumn{2}{|c|}{$\begin{array}{c}\text { mild diabetic } \\
\text { macular edema } \\
(\mathrm{n}=5)\end{array}$} & \multicolumn{2}{|c|}{$\begin{array}{c}\text { moderate diabetic } \\
\text { macular edema } \\
(\mathrm{n}=12)\end{array}$} & \multicolumn{2}{|c|}{$\begin{array}{c}\text { severe diabetic } \\
\text { macular edema } \\
(n=133) \\
\end{array}$} & \\
\hline & & & $\mathrm{N}$ & $\%$ & $\mathrm{~N}$ & $\%$ & $\mathrm{n}$ & $\%$ & \\
\hline \multirow{3}{*}{$\begin{array}{l}\text { Total } \\
\text { cholesterol }\end{array}$} & $<200$ & 78 & 4 & 80 & 8 & 66.67 & 66 & 49.62 & \multirow[t]{3}{*}{0.09} \\
\hline & 200 to 240 & 42 & 0 & 0 & 0 & 0.00 & 42 & 31.58 & \\
\hline & $>240$ & 30 & 1 & 20 & 4 & 33.33 & 25 & 18.80 & \\
\hline \multirow[t]{3}{*}{ Tryglycerides } & $<150$ & 102 & 3 & 60 & 5 & 41.67 & 94 & 70.68 & \multirow[t]{3}{*}{0.2} \\
\hline & 180 to 200 & 37 & 1 & 20 & 6 & 50.00 & 30 & 22.56 & \\
\hline & $>200$ & 11 & 1 & 20 & 1 & 8.33 & 9 & 6.77 & \\
\hline \multirow[t]{3}{*}{ HDL } & $<40$ & 52 & 3 & 60 & 9 & 75.00 & 40 & 30.08 & \multirow[t]{3}{*}{0.02} \\
\hline & 40 to 60 & 80 & 2 & 40 & 3 & 25.00 & 75 & 56.39 & \\
\hline & $>60$ & 18 & 0 & 0 & 0 & 0.00 & 18 & 13.53 & \\
\hline \multirow[t]{3}{*}{ LDL } & $<100$ & 68 & 2 & 40 & 4 & 33.33 & 62 & 46.62 & \multirow[t]{3}{*}{0.92} \\
\hline & 100 to 150 & 54 & 2 & 40 & 5 & 41.67 & 47 & 35.34 & \\
\hline & $>150$ & 28 & 1 & 20 & 3 & 25.00 & 24 & 18.05 & \\
\hline \multirow[t]{3}{*}{ UREA } & $<40$ & 111 & 5 & 100 & 9 & 75.00 & 97 & 72.93 & \multirow[t]{3}{*}{0.75} \\
\hline & 40 to 100 & 38 & 0 & 0 & 3 & 25.00 & 35 & 26.32 & \\
\hline & $>100$ & 1 & 0 & 0 & 0 & 0.00 & 1 & 0.75 & \\
\hline \multirow[t]{4}{*}{ creatinine } & $<1.2$ & 115 & 5 & 100 & 9 & 75.00 & 101 & 75.94 & \multirow[t]{4}{*}{0.77} \\
\hline & 1.3 to 5 & 33 & 0 & 0 & 3 & 25.00 & 30 & 22.56 & \\
\hline & 5 to 10 & 2 & 0 & 0 & 0 & 0.00 & 2 & 1.50 & \\
\hline & $>10$ & 0 & 0 & 0 & 0 & 0.00 & 0 & 0.00 & \\
\hline \multirow[t]{4}{*}{$\mathrm{HbA1c}$} & $<7 \%$ & 16 & 2 & 40 & 1 & 8.33 & 13 & 9.77 & \multirow[t]{4}{*}{0.39} \\
\hline & 7 to $9 \%$ & 69 & 2 & 40 & 6 & 50.00 & 61 & 45.86 & \\
\hline & 9 to $12 \%$ & 53 & 1 & 20 & 5 & 41.67 & 47 & 35.34 & \\
\hline & $>12 \%$ & 12 & 0 & 0 & 0 & 0.00 & 12 & 9.02 & \\
\hline
\end{tabular}

In our study CFT is divided into 5 different ranges. In fasting lipid profile, total cholesterol and triglycerides doesn't have any significant association with CFT. HDL and LDL cholesterol, urea, creatinine, HbAlc showed significant association with CFT. Increase in HDL and LDL were associated with increase in CFT. Increase in urea and creatinine levels, there was increase in percentage of patients with high CFT. Increased HbA1C levels were found in high proportion of patient in all range of central foveal thickness. 
Table 9: Central foveal thickness (CFT) and various risk factors

\begin{tabular}{|c|c|c|c|c|c|c|c|c|c|c|c|c|c|}
\hline \multirow{3}{*}{$\begin{array}{l}\text { Variables(mg/dl } \\
\text { HbA1C) }\end{array}$} & \multirow{3}{*}{ except } & \multirow{3}{*}{$\begin{array}{c}\text { Total } \\
\mathrm{N}=15 \\
0\end{array}$} & \multicolumn{10}{|c|}{ CENTRAL FOVEAL THICKNESS } & \multirow{3}{*}{ p-value } \\
\hline & & & \multicolumn{2}{|c|}{$200-250 \mu$} & \multicolumn{2}{|c|}{$251-350 \mu$} & \multicolumn{2}{|c|}{$351-450 \mu$} & \multicolumn{2}{|c|}{$451-550 \mu$} & \multicolumn{2}{|c|}{$>550 \mu$} & \\
\hline & & & $\begin{array}{c}\mathrm{n}=2 \\
8\end{array}$ & $\%$ & $\mathrm{n}=74$ & $\%$ & \multirow{2}{*}{$\begin{array}{c}\mathrm{n}=30 \\
20\end{array}$} & \multirow{2}{*}{$\begin{array}{c}\% \\
66.67 \\
\end{array}$} & \multirow{2}{*}{$\begin{array}{c}n=12 \\
8\end{array}$} & \multirow{2}{*}{$\begin{array}{c}\% \\
66.67\end{array}$} & \multirow{2}{*}{$\begin{array}{c}n=6 \\
2\end{array}$} & \multirow{2}{*}{$\begin{array}{c}\% \\
33.33\end{array}$} & \\
\hline & $<200$ & 78 & 15 & 53.57 & 33 & 44.59 & & & & & & & \\
\hline Iotal cholestrol & $>200$ & 72 & 13 & 46.43 & 41 & 55.41 & 10 & 33.33 & 4 & 33.33 & 4 & 66.67 & 0.19 \\
\hline \multirow{2}{*}{ Triglycerides } & $<15$ & 102 & 18 & 64.29 & 53 & 71.62 & 23 & 76.67 & 5 & 41.67 & 3 & 50.00 & \multirow{2}{*}{0.17} \\
\hline & $>150$ & 48 & 10 & 35.71 & 21 & 28.38 & 7 & 23.33 & 7 & 58.33 & 3 & 50.00 & \\
\hline \multirow{2}{*}{ HDL } & $<40$ & 52 & 17 & 60.71 & 20 & 27.03 & 11 & 36.67 & 3 & 25.00 & 1 & 16.67 & \multirow{2}{*}{0.02} \\
\hline & $>40$ & 98 & 11 & 39.29 & 54 & 72.97 & 19 & 63.33 & 9 & 75.00 & 5 & 83.33 & \\
\hline \multirow{2}{*}{ LDL } & $<100$ & 68 & 9 & 32.14 & 33 & 44.59 & 22 & 73.33 & 1 & 8.33 & 3 & 50.00 & \multirow{2}{*}{0.001} \\
\hline & $>100$ & 82 & 19 & 67.86 & 41 & 55.41 & 8 & 26.67 & 11 & 91.67 & 3 & 50.00 & \\
\hline \multirow[b]{2}{*}{ Urea } & $<40$ & 111 & 22 & 78.57 & 62 & 83.78 & 23 & 76.67 & 2 & 16.67 & 2 & 33.33 & \multirow{2}{*}{$<0.001$} \\
\hline & $>40$ & 39 & 6 & 21.43 & 12 & 16.22 & 7 & 23.33 & 10 & 83.33 & 4 & 66.67 & \\
\hline \multirow{2}{*}{ Creatinine } & $<1.2$ & 115 & 19 & 67.86 & 63 & 85.14 & 24 & 80.00 & 7 & 58.33 & 2 & 33.33 & \multirow{2}{*}{0.01} \\
\hline & $>1.2$ & 35 & 9 & 32.14 & 11 & 14.86 & 6 & 20.00 & 5 & 41.67 & 4 & 66.67 & \\
\hline \multirow{2}{*}{$\mathrm{HbA1c}$} & $<7 \%$ & 16 & 3 & 10.71 & 2 & 2.70 & 6 & 20.00 & 4 & 33.33 & 1 & 16.67 & \multirow{2}{*}{0.01} \\
\hline & $>7 \%$ & 134 & 25 & 89.29 & 72 & 97.30 & 24 & 80.00 & 8 & 66.67 & 5 & 83.33 & \\
\hline
\end{tabular}

\section{Discussion}

In our study, age did not show statistically significant correlation in both groups with maculopathy, which was in concurrence with study done by Teiko Yamamoto, Satoshi Iimuro et.al. ${ }^{3}$ However in our study severe form of maculopathy was seen in older group patients 30 to 70 years of age, Which was in concurrence with the study done by Klein et.al., higher rates of maculopathy were found in the presence of nonproliferative diabetic retinopathy in older as compared to younger subjects. ${ }^{4}$ Age-corrected prevalence rates suggest that there is no definite age interaction with duration of disease. ${ }^{5}$

In fasting lipid profile only HDL cholesterol level showed significant association with severity of macular edema, which was in concurrence with the study done by Teiko Yamamoto, Satoshi Iimuro et.al. showed HDL was associated with severity of retinopathy. ${ }^{6}$ Other type of cholesterol, urea, creatinine and $\mathrm{HbA} 1 \mathrm{C}$ were not significantly associated with macular edema. Dyslipidemia has been implicated as an independent risk factor for vision loss and DME. ${ }^{7}$ However, no single lipid measure has been found to be consistently associated with diabetic retinopathy or diabetic macular edema (DME). ${ }^{8}$ Increase in central foveal thickness was significantly associated with decrease in levels of HDL and increase in LDL cholesterol.

In our study increase in urea and creatinine levels were found to increase the central foveal thickness. A study done by Aiello LM et.al, showed higher frequency of macular oedema found in nephropathic diabetic patients with proteinuria. ${ }^{9}$ Romero et al. also noted that there was no significant correlation between microangiopathy of the kidney and macular edema. While the correlation between macular edema was not significant in normal diabetes patients, it was significant in patients with severe renal dysfunction. ${ }^{10}$

Poor glycaemic control when HbA1c levels more than $7 \%$ were found to increase the CFT in my study, which was in consistent with the similar study done by T-H Chou, P-C Wu et. al, concluded that patients with $\mathrm{HbA1c}$ of 8 or above had an increase in macular thickness as measured by OCT. ${ }^{11}$

The Diabetes Control and Complications trial reported that the cumulative incidence of severe non-proliferative retinopathy and proliferative retinopathy increased with increasing duration of diabetes $^{12}$ Klein et al. also showed that there was an increase in the prevalence of any type of retinopathy, or proliferative retinopathy, with increasing duration of diabetes. ${ }^{13,14}$ They also reported that the duration of diabetes was a significant risk factor for the development of macular edema in older patients. ${ }^{15}$ However in our study we were not able to show significant association of diabetic maculopathy with duration of diabetes mellitus and hypertension, which could be due to smaller sample size of my study. 
Duration of hypertension and severity of maculopathy did not show any significant association in my study. To my best knowledge there was no prior report between the correlation of duration of hypertension and diabetic maculopathy. However United Kingdom Prospective Diabetes Study reported that the occurrence of retinopathy was associated with higher systolic blood pressure ${ }^{16}$, and Cahill et al. reported that the incidence of retinopathy was associated with systemic hypertension in patients diagnosed after the age of 70 years. ${ }^{17}$ However, a study done by Klein R et al. showed that the blood pressure was not significantly correlated with the incidence or progression of retinopathy in the older onset group. ${ }^{18}$

\section{Conclusion}

Poor glycaemic control as evidenced by HbA1C $>7 \%$ associated with increase central foveal thickness. Hyperlipidaemia in the form increase in LDL and decrease in HDL has got a statistically significant increase in central foveal thickness. Late stage of Nephropathy evidenced by increase in serum urea and creatinine do increase the macular edema. Age does not have influence on the severity of diabetic maculopathy. Duration of hypertension, diabetes and coronary artery disease does not have influence over diabetic maculopathy.

\section{References}

1. Miljanovic B, Glynn RJ, Nathan DM, et al: A prospective study of serum lipids and risk of diabetic macular edema in type 1 diabetes. Diabetes 2004; 53:2883-2892

2. Zander E, Herfurth S, Bohl B, et al: Maculopathy in patients with diabetes mellitus type 1 and type 2: associations with risk factors. Br. J. Ophthalmol 2000; 84:871-876.

3. Teiko Yamamoto, Satoshi Iimuro et.al Prevalence and risk factors for diabetic maculopathy, and its relationship to diabetic retinopathy in elderly Japanese patients with type 2 diabetes mellitus. Geriatr GerontolInt 2012; 12 (Suppl. 1): 134-140g

4. Klein R, Klein BEK, Moss SE, et al. The Wisconsin Epidemiologic Study of Diabetic Retinopathy IV. Diabetic macular edema. Ophthalmology 1984;91:1464-74g

5. Cugati S, Kifley A, Mitchell P, Wang JJ: T emporal trends in the age-specific prevalence of diabetes and diabetic retinopathy in older persons: Populationbased survey findings. Diabetes Res. Clin. Pract. 2006

6. Teiko Yamamoto, Satoshi Iimuro et.al Prevalence and risk factors for diabetic maculopathy, and its relationship to diabetic retinopathy in elderly Japanese patients with type 2 diabetes mellitus. Geriatr Gerontol Int 2012; 12 (Suppl. 1): 134-140g

7. Ferris FL 3rd, Chew EY, Hoogwerf BJ. Serum lipids and diabetic retinopathy. Early treatment diabetic retinopathy study research group. Diabetes Care. 1996; 19:1291-3.

8. Ding J, Wong TY. Current epidemiology of diabetic retinopathy and diabetic macular edema. CurrDiab Rep. 2012;12:346-54

9. Aiello LM, Rand LI, Briones JC, et al. Nonocular clinical risk factors in the progression of diabetic retinopathy. In: Little HL, Jack RL, Patz A, Forsham PH, eds. Diabetic retinopathy. New York: Thieme-Stratton, 1983:21-31._

10. Romero P, Baget M, Mendez I, et al. Diabetic macular edema and its relationship to renal microangiopathy: a sample of type I diabetes mellitus patients in a 15year follow up study. J Diabetes Complications. 2007;21:172-180.

11. T-H Chou, P-C Wu et. al Relationship of diabetic macular oedema with glycosylated haemoglobin. Eye (2009) 23, 1360-1363

12. Diabetes Control and Complications trial Research Group. The effect of intensive 
diabetes treatment on the progression of diabetic retinopathy in insulin-dependent diabetes mellitus. Arch Ophthalmol 1995; 113: 36-51

13. Klein R, Moss SE, Klein BE, Davis MD, De Mets DL. The Wisconsin epidemiological study of diabetic retinopathy. XI. The incidence of macular edema. Ophthalmology 1989; 96: 15011510

14. Klein R, Klein BEK, Moss SE, et al. Th e Wisconsin Epidemiologic Study of Diabetic Retinopthy XIV. Ten-year incidence and progression of diabetic retinopathy. Arch Ophthalmol 2008; 112:1217-28.

15. Klein R, Klein BE, Moss SE, Davis MD, DeMets DL. The Wisconsin Epidemiologic Study of Diabetic Retinopathy, II. Prevalence and risk of diabetic retinopathy when age at diagnosis is less than 30 years. Arch Ophthalmol1984; 102: 520-526.

16. Stratton IM, Kohner EM, Aldington SJ et al. UKPDS 50: risk factors for incidence and progression of retinopathy in type II diabetes over 6 years from diagnosis. Diabetologia2001; 44: 156

17. Cahill M, Halley A, Codd $M$ et al. Prevalence of diabetic retinopathy in patients with diabetes mellitus diagnosed after the age of 70 years. Br J Ophthalmol 1997; 81: 218-222

18. Klein R, Klein BE, Moss SE, Davis MD, DeMets DL. Is blood pressure a predictor of the incidence or progression of diabetic retinopathy? Arch Intern Med 1989; 149: 2427- 2432 . 